\title{
Germination and Seedling Growth of Hybrid and Madura Local Corn on Salt Stress
}

\author{
Kelik P. W. Sukma ${ }^{1}$, Isdiana Suprapti ${ }^{2} *$, Budi Setiadi Daryono ${ }^{3}$, Purnomo $^{3}$ \\ ${ }^{I}$ Department Agrotechnology, Faculty Agriculture, Universitas Islam Madura, Pamekasan, East Java, Indonesia \\ ${ }^{2}$ Department Agribussines, Faculty Agriculture, Universitas Trunojoyo Madura, Bangkalan, East Java, Indonesia \\ ${ }^{3}$ Faculty of Biology, Universitas Gadjah Mada, Yogyakarta, Indonesia \\ *Corresponding author. Email: ana.utm@gmail.com
}

\begin{abstract}
Madura Salt Tolerance Corn (var. Duko and var. Elos) and Hybrid Corn (Sukmaraga and Anoman-1) were germinated on $0,100,200,300$ and $400 \mathrm{mM} \mathrm{NaCl}$ for 7 days. Then its planted by wick system hydroponic also on the same $\mathrm{NaCl}$ concentration for 14 days, conducted by using randomized block design with 4 replications. The results were all varieties couldn't germinated on 300 and $400 \mathrm{mM} \mathrm{NaCl}$ and Anoman-1 couldn't be germinated from $200 \mathrm{mM} \mathrm{NaCl}$. Duko had the highest value of Full Germination Percent (FGP), Mean Germination Time (MGT), Germination Index (GI), and Salt Tolerance Index (STI) at $200 \mathrm{mM} \mathrm{NaCl}$. Sukmaraga had the highest value of height and shoot growth ratio of the seedling.
\end{abstract}

Keywords: corn, salt, germination, seedling

\section{INTRODUCTION}

Corn is one of the main foods and essential commodities in agribusiness [1] and important in improving the agricultural economy in the world [2]. Corn production in Indonesia is 19,6 million tons, the second's food production after rice [3]. The total usage of maize would increase, but the land would decrease because of land conversion into residential. It makes difficult to fulfill maize need [4].

Land expansion is needed to fulfill it. Corns can be planted in marginal lands, such as dry and saline soils. Saline soils are the largest marginal land in Indonesia. Indonesia has shorelines 106 thousand kilometers and land potential 1,06 million hectares [5] It can be planted maize, but the main challenge the high content of salt will decrease productivity. Salinity is one of the main limiting factors that can decrease growth and productivity of maize [6] and many plant species [7]

Corn var. Duko and Elos are Madura local corn which has the highest resistance to salinity [8]. This research objective was to compare the resistance of both corn to var. Sukmaraga and Anoman ${ }^{-1}$. [9] explained that Sukmaraga had middle resistance to salt stress and Anoman had a low one.

\section{METHODS}

Plant material and Research Design

Corn from the research of [8] was var. Elos (El.), Duko (Du.), The hybrid corns are Sukmaraga (Su) and Anoman1 (An.) from Research Center of Cerealia Maros, South Sulawesi, Indonesia. Seeds with similar size and weight were selected to get the same germination rate. Seeds were surface sterilized in $2 \%(\mathrm{v} / \mathrm{v}) \mathrm{NaOCl}$ for $10 \mathrm{~min}$ and washed by distilled water. Thirty seeds were placed on filter papers that contained $\mathrm{NaCl}$ solution $(0,100,200,300$ and $400 \mathrm{mM}$ ) and located in $15 \mathrm{~cm}$ diameter sterile Petri dishes.

It was conducted by using randomized block design with 4 replications. Significant differences between treatments were determined by DMRT $5 \%$.

\section{Germination Assays}

Germination was done at room temperature $\left( \pm 27^{\circ} \mathrm{C}\right)$. The seed weight was measured for 3 days. The seed germination was counted every day for 7 (seven) days. Germination of seed was counted when the emergence of radicles $\geq 2 \mathrm{~mm}[10]$.

Full Germination Percent (FGP) was calculated by equation

$$
F G P=\frac{\text { number of germinated seeds }}{\text { total seeds number }} \times 100 \%
$$

The Mean Germination Time (MGT) was calculated everyday for each replication used the equation [10], [11]

$$
M G T=\frac{\text { number of seeds newly germinated at day } D}{\text { number of all germinated seeds }}
$$

Germination Index (GI) was calculated by equation [12],

$$
G I=\sum\left(\frac{\text { the number of seeds germinated on } D \text { day }}{\text { number of days up to } D \text { day }}\right)
$$

Salt Tolerance Index (STI) on germination was calculated by equation [12].

$S T I=\frac{\text { germination } / \text { growth in a particular treatment }}{\text { germination } / \text { growth } \text { in the control }}$ 


\section{Seedling Assays}

The seedlings were cultivated by wick system hydroponic. The media used [13] added by $\mathrm{NaCl} 0,100 \mathrm{mM}$ and 200 $\mathrm{mM}$. It had the same replication with germination treatment. Plants height measured at 21 days after cultivated. Plants lea2ves at 21 days after cultivated were cut and measured Proline content, measured by ninhydrin methods. [14].

\section{RESULTS AND DISCUSSION}

\section{Germination Character}

Table 1 showed that all varieties decrease germination ability. All varieties could not be germinated on $300 \mathrm{mM}$ and $400 \mathrm{mM}$ salt $(\mathrm{NaCl})$. They could be germinated until $200 \mathrm{mM}$. The value of FGP, GI and STI of Madura local corns were better than hybrid corn. Reducing germination ability also reported by the previous researcher such as [15], [16], [17].

Table 1. Germination Character of Hybrid and Madura Local Corn on Difference Concentration Salt Solution

\begin{tabular}{|c|c|c|c|c|c|c|}
\hline \multirow{2}{*}{ Par. } & \multirow{2}{*}{ Var } & \multicolumn{5}{|c|}{ Salt Treatment (mM) } \\
\hline & & $\mathbf{0}$ & 100 & 200 & 300 & 400 \\
\hline \multirow{4}{*}{$\begin{array}{l}\text { FGP } \\
(\%)\end{array}$} & El. & $100 \mathrm{e}$ & $92.5 \mathrm{~cd}$ & $80,5 \mathrm{c}$ & $0 \mathrm{a}$ & $0 \mathrm{a}$ \\
\hline & Du. & $100 \mathrm{e}$ & $100 \mathrm{e}$ & $90,2 \mathrm{~cd}$ & $0 \mathrm{a}$ & $0 \mathrm{a}$ \\
\hline & Su. & $100 \mathrm{e}$ & $100 \mathrm{e}$ & $75,2 \mathrm{~cd}$ & $0 \mathrm{a}$ & $0 \mathrm{a}$ \\
\hline & An. & $100 \mathrm{e}$ & $80 \mathrm{c}$ & $20,5 \mathrm{~b}$ & $0 \mathrm{a}$ & $0 \mathrm{a}$ \\
\hline \multirow{4}{*}{$\begin{array}{l}\text { MGT } \\
\text { (d) }\end{array}$} & El. & $2.64 \mathrm{~b}$ & $4.66 \mathrm{c}$ & $4.99 \mathrm{~cd}$ & $0 \mathrm{a}$ & $0 \mathrm{a}$ \\
\hline & Du. & $3.65 \mathrm{~b}$ & $4.68 \mathrm{c}$ & $5.44 \mathrm{~d}$ & $0 \mathrm{a}$ & $0 \mathrm{a}$ \\
\hline & $\mathrm{Su}$. & $4.32 \mathrm{c}$ & $4.53 \mathrm{c}$ & $7.00 \mathrm{e}$ & $0 \mathrm{a}$ & $0 \mathrm{a}$ \\
\hline & An. & $3.25 \mathrm{~b}$ & $4.47 \mathrm{~d}$ & $7.30 \mathrm{e}$ & $0 \mathrm{a}$ & $0 \mathrm{a}$ \\
\hline \multirow[t]{4}{*}{ GI } & El. & $9.73 \mathrm{f}$ & $4.29 \mathrm{c}$ & $3.12 \mathrm{bc}$ & $0 \mathrm{a}$ & $0 \mathrm{a}$ \\
\hline & Du. & $5.77 \mathrm{e}$ & $4.48 \mathrm{c}$ & $2.45 \mathrm{~b}$ & $0 \mathrm{a}$ & $0 \mathrm{a}$ \\
\hline & $\mathrm{Su}$. & $4.79 \mathrm{~cd}$ & $4.47 \mathrm{c}$ & $0.14 \mathrm{a}$ & $0 \mathrm{a}$ & $0 \mathrm{a}$ \\
\hline & An. & $5.54 \mathrm{~d}$ & $4.67 \mathrm{~cd}$ & $0.04 \mathrm{a}$ & $0 \mathrm{a}$ & $0 \mathrm{a}$ \\
\hline \multirow[t]{4}{*}{ STI } & El. & $1.00 \mathrm{c}$ & $0.93 \mathrm{c}$ & $0.81 \mathrm{c}$ & $0 \mathrm{a}$ & $0 \mathrm{a}$ \\
\hline & Du. & $1.00 \mathrm{c}$ & $1.00 \mathrm{c}$ & $0.90 \mathrm{c}$ & $0 \mathrm{a}$ & $0 \mathrm{a}$ \\
\hline & $\mathrm{Su}$. & $1.00 \mathrm{c}$ & $1.00 \mathrm{c}$ & $0.75 \mathrm{c}$ & $0 \mathrm{a}$ & $0 \mathrm{a}$ \\
\hline & An. & $1.00 \mathrm{c}$ & $0.80 \mathrm{bc}$ & $0.21 \mathrm{~b}$ & $0 \mathrm{a}$ & $0 \mathrm{a}$ \\
\hline \multirow{4}{*}{$\begin{array}{l}\text { Seed } \\
\text { gowt } \\
\text { h } \\
\text { weig } \\
\text { ht } \\
\text { (g) }\end{array}$} & El. & $0.81 \mathrm{e}$ & $0.76 \mathrm{~d}$ & $0.66 \mathrm{c}$ & $0.61 \mathrm{c}$ & $0.55 \mathrm{bc}$ \\
\hline & Du. & $0.33 \mathrm{a}$ & $0.32 \mathrm{a}$ & $0.31 \mathrm{a}$ & $0.31 \mathrm{a}$ & $0.31 \mathrm{a}$ \\
\hline & $\mathrm{Su}$. & $1.11 \mathrm{~g}$ & $0.91 \mathrm{~g}$ & $0.55 \mathrm{bc}$ & $0.54 \mathrm{bc}$ & $0.51 \mathrm{~b}$ \\
\hline & An. & $1.10 \mathrm{~g}$ & $0.89 \mathrm{f}$ & $0.52 . \mathrm{b}$ & $0.51 \mathrm{~b}$ & $0.49 \mathrm{~b}$ \\
\hline
\end{tabular}

Note : number followed by same letter on row and column, not significantly different on DMRT $5 \%$.

In normal water $(0 \mathrm{mM}$ salt $)$, seeds could germinate normally because water and another nutrient normally absorbed. Increasing salt concentration in the medium can increase the osmotic potential, thus prevent the uptake of water, indicated by decreasing seed growth weight (Table 1). Existing water was needed to mobilize nutrients for germination. Increasing of salt, also makes the ions $\mathrm{Na}^{+}$or $\mathrm{Cl}^{-}$may be toxic to the embryo [12]. The toxicity of $\mathrm{NaCl}$ reported by [18] and [19]. Finally, its inhibits germination ability [15], [17].

\section{Seedling Character}

Tabel 2 shows that salt stress reduced all corn's height. On normal water, hybrid corns were taller than local corns. On $200 \mathrm{mM} \mathrm{NaCl}$, both hybrid and local corns' height were not significantly different. Reducing plant growth caused by osmotic stress, ion toxicity and nutritional imbalance. Osmotic stress occurs because salt on medium restricts water potential and plant root water conductivity. It reduces cell membrane permeability and water influx. Ions toxicity made by sodium and chloride. Sodium and chloride also reduce mineral uptake of the plants, which would make nutritional imbalance [20].

Table 2. Seedling Character of Hybrid and Madura Local Corn on Difference Concentration Salt Solution

\begin{tabular}{|l|l|r|r|r|}
\hline \multirow{2}{*}{$\begin{array}{c}\text { Para- } \\
\text { meter }\end{array}$} & \multirow{2}{*}{ Var. } & \multicolumn{3}{|c|}{ Salt Treatment } \\
\cline { 3 - 5 } & & $\mathbf{0} \mathbf{~ m M}$ & $\mathbf{1 0 0} \mathbf{~ m M}$ & $\mathbf{2 0 0} \mathbf{~ m M}$ \\
\hline Height & El. & $30,63 \mathrm{c}$ & $26,61 \mathrm{~b}$ & $21,82 \mathrm{a}$ \\
\hline & Du. & $31,83 \mathrm{c}$ & $24,12 \mathrm{ab}$ & $20,75 \mathrm{a}$ \\
\hline & Su. & $37,63 \mathrm{~d}$ & $29,08 \mathrm{c}$ & $21,75 \mathrm{a}$ \\
\hline & An. & $33,03 \mathrm{c}$ & $24,75 \mathrm{ab}$ & $22,25 \mathrm{a}$ \\
\hline $\begin{array}{l}\text { Growth } \\
\text { ratio }\end{array}$ & El. & 1,28 & 1,21 & 1,35 \\
\hline & Du. & 1,49 & 1,19 & 1,64 \\
\hline & Su. & 1,32 & 1,89 & 1,71 \\
\hline & An. & 1,56 & 2,06 & 2,00 \\
\hline Proline & El. & $1,08 \mathrm{a}$ & $107,67 \mathrm{f}$ & $140,51 \mathrm{~g}$ \\
\hline & Du. & $1,31 \mathrm{a}$ & $93,29 \mathrm{ef}$ & $193,66 \mathrm{~h}$ \\
\hline & Su. & $9,53 \mathrm{~b}$ & $31,12 \mathrm{~d}$ & $83,44 \mathrm{e}$ \\
\hline & An. & $16,81 \mathrm{c}$ & $104,90 \mathrm{f}$ & - \\
\hline
\end{tabular}

Note : number followed by same letter on row and column, not significantly different on DMRT 5\%.

Table 2 also showed increasing of $\mathrm{NaCl}$ content increase proline level of all varieties. That result was similar to previous research such as [21], [22], and [23]. While plants under stress, plant produce reactive oxygen species (ROS) such as hydrogen peroxide, superoxide, singlet oxygen, and hydroxyl radical. ROS can increase lipid peroxidation, protein degradation and DNA mutation [24]. ROS activity can be blocked by proline and glycine betaine. Increasing of proline content in hybrid and local corn could show plant activity to block ROS activity. According to previous research, existing of proline on stress concern with cell 
membrane stabilizing [25], osmotic balance [26], the arrangement of cytosol acidity and $\mathrm{NAD}^{+} / \mathrm{NADH}$.

\section{CONCLUSION}

Salt stress reduces germination ability and seedling growth of hybrid and local Madura corns. Corn var. Duko had the highest germination ability but Var. Sukmaraga had the highest on seedling growth.

\section{ACKNOWLEDGMENT}

Thanks for Ministry of Research, Technology and High Education that had given a research grant in the fiscal year 2019.

\section{REFERENCES}

[1] Kuruseng M. A., M. Farid M, "Analysis of the heritability of maize resistant salinity and drought result of mutations induced by gamma rays", Jurnal Agrisistem, Vol. 5(1), pp 30-39, 2009.

[2] Balkrishna, R. A. and S. S. Shankarrao, "In vitro screening and molecular genetic markers associated with salt tolerance in maize", African Journal of Biotechnology, Vol. 12(27), pp 42514255, 2013. Doi. 10.5897/AJB2012.2992

[3] BPS, "Produksi jagung menurut provinsi (ton), 1993-2015. Access on www.bps.go.id at 10 August 2019.

[4] Departement of Agriculture, "Prospect and direction of maize agribusiness development", Agency for Agricultural Research and Development, Departement of Agriulture, 2005

[5] Suprapto, A., "Land and water resources development in Indonesia", in Yuwono, N. W., "Membangun kesuburan tanah di lahan marginal", Jurnal Ilmu Tanah dan Lingkungan, Vol. 9 (2), pp 137-141, 2009.

[6] Yumurtaci, A., H. Sipahi, L. Zhao, "Genetic analysis of microsatellite markers for salt stress in two contrasting maize parental lines and their RIL population", Acta Bot Croat, Vol. 76(1), 2017. DOI: $10.1515 /$ botcro-2016-0042.

[7] Flowers, T. J., "Improving crop salt tolerance", J. Exp Bot, Vol. 396(55), pp 307-309, 2004.

[8] Sukma, K. P. W., B. S. Daryono, Purnomo, I. Suprapti, "Salinity resistance of seven varieties of Madura corn on early stage of growth. 4th International Conference on Food and Agriculture Resources (FANRes 2018)", Atlantis Press : Advances in Engineering Research. 2018, Vol. 172, pp 181-184, 2018

[9] Dachlan, A., N. Kasim, A. K. Sari, "Uji ketahanan salinitas beberapa varietas jagung (Zea mays, L.) dengan menggunakan agen seleksi $\mathrm{NaCl}^{\prime}$, Biogenesis, Vol. 1(1), pp 9-17, 2013.

[10] Aliu, S., I. Rusinovci, S. Fetahu, B. Gashi, E. Simeonovska, L. Rozman, "The effect of salt stress on the germination of maize (Zea mays L.) seeds and photosynthetic pigments", Acta agriculturae Slovenica, Vol. 105 - 1, pp 85 - 94, 2015.

[11] Soltani E., F. Gahderi-Far., C. C. Baskin, J. M. Baskin, "Problem with using mean germination time to calculate rate of seed germination", Australian Journal of Botany, 2015.

[12] Khayatnezhad M. and R. Gholamin, "Effects of salt stress levels on five maize (Zea mays L.) cultivars at germination stage", African Journal of Biotechnology, Vol. 10(60), 2011.

[13] Hoagland, D. R. And D. I. Arnon, "The waterculture methods for growing plants without soil", California Agricultural Experiment Station, Circular 347, 1950.

[14] Bates, L. S., R. P. Waldren, I. D. Teare, "Rapid determination of free proline water stress studies. Plant and soil", Vol 39(1), 1973. https://link.springer.com/article/10.1007/BF00018 $\underline{060}$

[15] Carpici, E. B. N. Celik, G. Bayram, "Effects of salt stress on germination of some maize (Zea mays L.) cultivars", African Journal of Biotechnology, Vol. 8 (19), pp. 4918-4922, 2009.

[16] Almodares A, M. R., M. R. Hadi, B. Dosti, "Effects of salt stres on germination percentage and seedling growth in sweet sorghum cultivars", J. Biological Sci., Vol. 7(8), pp 1492-1495, 2007.

[17] Blanco F. F. , M. V. Folegatti, H. R. Gheyi, P. D. Fernandes, "Emergenceand growth of corn and soybean under saline stress", Sci. Agric. Piracicaba, Braz., Vol. 64(5), pp 451-459, 2007.

[18] Kronzucker, H. J., D. Coskun, L. M. Schulze, J. R. Wong, D. T. Britto, "Sodium as nutrient and toxicant", Plant Soil, 369, pp 1-23, 2013

[19] Flowers, T. J., R Munns, T. J. Colmer,"Sodium chloride toxicity and cellular basis of salt tolerance in halophytes", Annals of Botany, 115, pp 419-431, 2015

[20] Abbasi, H. , M. Jamil, A. Haq, S. Ali, R. Ahmad, Z. Malik, Parveen, "Salt stress manifestation on plants, mechanism of salt tolerance and potassium role in alleviating it: a review", ZemdirbysteAgriculture, Vol. 103( 2). Pp 229-238, 2016. DOI 10.13080/z-a.2016.103.030

[21] Dogan M., R. Tipirdamaz, Y. Demir, "Salt resistance of tomato species grown in sand culture", Plant, Soil and Environment, Vol. 56, pp 499-507, 2010.

[22] Nabati J., M. Kafi, A. Nezami, P. R. Moghaddam, A. Masoumi, M. Z. Mehrjerdi, "Effect of salinity on biomass production and activities of some key enzymatic antioxidants in burning bush (Kochia scoparia)", Pakistan. Journal of Botany, Vol. 43, pp 539-548, 2011. 
[23] Huang, Z., 1. Zhao, D. Chen, M. Liang, Z. Liu, H. Shao, X. Long, "Salt stress encourages proline accumulation by regulating proline biosynthesis and degradation in Jerusalem artichoke plantlets, PLoS One, Vol. 8(4), pp e62085, 2013.

[24] Pitzschke A., C. Forzani, H. Hirt, "Reactive oxygen species signaling in plants", Plant Signaling and Behavior, Vol. 8, pp 1757-1764, 2006. http://dx.doi.org/10.1089/ars.2006.8.1757.

[25] Gadallah M. A. A., "Effects of proline and glycinebetaine on Vicia faba responses to salt stress", Biologia Plantarum, Vol. 42, pp 249-257, 1999.

http://dx.doi.org/10.1023/A:1002164719609.

[26] Kishor, P. B. K., S. Sangam, R. N. Amrutha, P. S. Laxmi, K. R. Naidu, K. R. S. S. Rao, Sreenath Rao, K. J. Reddy, P. Theriappan and N. Sreenivasulu, "Regulation of proline biosynthesis, degradation, uptake and transport in higher plants: Its implications in plant growth and abiotic stress tolerance", Current Science, Vol. 88, pp 424-438, 2005. 